\title{
An ideal combination for marine turtle conservation: exceptional nesting season, with low nest predation resulting from effective low-cost predator management
}

\author{
Richard Engeman, R. Erik Martin, John Woolard, Margo Stahl \\ Charles Pelizza, Anthony Duffiney and Bernice Constantin
}

\begin{abstract}
We examined impacts from effective predator management on nesting success of marine turtles in an exceptional nesting year at Hobe Sound National Wildlife Refuge, Florida, USA, a beach with a high density of nesting marine turtles that has a history of severe nest predation. Historically up to $95 \%$ of nests were predated, primarily by raccoons Procyon lotor and, more recently, armadillos Dasypus novemcinctus. Predator control was identified as the most important conservation tool for marine turtle reproduction. Predator management by refuge staff as ancillary duties typically only held predation levels to c. $50 \%$. However, when experts in predator control were employed predation was substantially reduced. An extraordinary opportunity to evaluate the biological and economic benefits of this management approach occurred in 2008, a year with exceptionally heavy nesting. Loggerhead turtle Caretta caretta nesting resurged, green Chelonia mydas and leatherback Dermochelys coriacea turtles nested in record numbers, producing twice or more than their median number of nests, and the first Kemp's ridley Lepidochelys kempii nest was observed. Overall predation was $14.7 \%$, resulting in an estimated $>128,000$ additional hatchlings emerging compared to estimates had no predator management been in place and historical predation rates occurred, and $>56,000$ hatchlings more than expected had predator management been conducted as ancillary duties rather than by experts. The USD 12,000 investment for expert predator management equated to only USD 0.09 spent for each additional hatchling produced compared to the scenario of
\end{abstract}

RICHARD ENGEMAN (Corresponding author) National Wildlife Research Center, 4101 LaPorte Ave, Ft Collins, Colorado 80521-2154, USA. E-mail richard.m.engeman@aphis.usda.gov

R. Erik Martin Ecological Associates, Inc., Jensen Beach, Florida, USA

John Woolard, Anthony Duffiney and Bernice Constantin* USDA/ APHIS/Wildlife Services, Gainesville, Florida, USA

Margo Stahl and Charles Pelizza Hobe Sound National Wildlife Refuge, Hobe Sound, Florida, USA

${ }^{*}$ Current address: Pelican Island and Archie Carr National Wildlife Refuge, Florida, USA

Received 23 August 2010. Revision requested 14 December 2010.

Accepted 14 January 2011. First published online 1 November 2011. no predator control and only USD 0.21 compared to the scenario of predator control as ancillary duties.

Keywords Armadillo, bioeconomics, endangered species, Florida, green turtle, leatherback turtle, loggerhead turtle, raccoon

\section{Introduction}

A ll marine turtle species are considered threatened and successful reproduction is therefore of paramount importance. Five species nest on Florida's beaches, which are of global importance for marine turtle nesting and account for c. $90 \%$ of loggerhead Caretta caretta nesting activity in the USA (Hopkins \& Richardson, 1984; National Marine Fisheries Service and U.S. Fish \& Wildlife Service, 2008). This nesting aggregation is one of the two most important globally for the loggerhead turtle (National Marine Fisheries Service \& U.S. Fish \& Wildlife Service, 2008). Florida's beaches also support nearly $100 \%$ of Atlantic green turtle Chelonia mydas nesting in the USA and are vital for green turtle nesting in the western Atlantic (Witherington et al., 2006).

Predation is one of the greatest impediments to successful marine turtle nesting on Florida's beaches, with many beaches experiencing substantial losses (e.g. $\geq 80 \%$ ) unless nest predators are managed (NRC, 1990; Bain et al., 1997; Engeman et al., 2003, 2010). Predation threatens many rare species (Hecht \& Nickerson, 1999), with the deleterious impacts from predation compounded by habitat loss (Reynolds \& Tapper, 1996). Both problems apply to marine turtle nesting in Florida, often making human intervention necessary to ensure adequate turtle reproduction.

Mammalian meso-predators are the most destructive nest predators globally (Stancyk, 1982). Many species are responsible for losses along Florida's beaches (Stancyk, 1982; Dodd, 1988), with raccoons Procyon lotor the most ubiquitous and destructive nest predators, affecting marine turtle reproduction throughout Florida (Stancyk, 1982; Williams-Walls et al., 1983; NRC, 1990; Mroziak et al., 2000; Engeman et al., 2003; Garmestani \& Percival, 2005). Raccoons are native, abundant and flourish in association with humans (Dickman \& Doncaster, 1987; Riley et al., 
1998; Smith \& Engeman, 2002). Florida is also one of the two US states with the most severe invasive species problems (US Congress, 1993; Schmitz \& Brown, 1994), with species such as nine-banded armadillos Dasypus novemcinctus, feral swine Sus scrofa, coyotes Canis latrans and red fox Vulpes vulpes identified as significant primary nest excavators and predators at various beaches (Drennen et al., 1989; Bain et al., 1997).

A particularly important nesting beach is protected at Hobe Sound National Wildlife Refuge on Jupiter Island, Florida, where undeveloped and protected beach habitat is provided for nesting by up to four marine turtle species: loggerhead, leatherback Dermochelys coriacea, green and, rarely, Kemp's ridley Lepidochelys kempii. Each is federally listed as threatened or endangered (U.S. Fish \& Wildlife Service, 1994), and categorized on the IUCN Red List (IUCN, 2010) as Endangered (loggerhead, green) and Critically Endangered (leatherback, Kemp's ridley). This beach has a long history of significant nest predation. Raccoons have always been a threat to marine turtle reproduction and in recent years nine-banded armadillos have become an equal threat to marine turtle nests (Drennen et al., 1989; Bain et al., 1997; U.S. Fish \& Wildlife Service, 2000; Engeman et al., 2003, 2005, 2006). Minor additional predation by opossums Didelphis virginiana, spotted skunks Spilogale putorius and bobcats Felis rufus also occurs (Woolard et al., 2004; Martin et al., 2005). Predator management can greatly assist many rare species threatened by predation (Engeman et al., 2009), including marine turtle nests at this Refuge (Bain et al., 1997; U.S. Fish \& Wildlife Service, 2000; Engeman et al., 2003, 2005, 2006).

Prior to managing predators up to $95 \%$ of turtle nests were predated at Hobe Sound National Wildlife Refuge (Bain et al., 1997). Predator removal was identified as the most important management programme at the beach (Bain et al., 1997; U.S. Fish \& Wildlife Service, 2000). Predator control by refuge staff in addition to their regular duties typically maintained predation losses to c. 50\% (Engeman et al., 2003). Predator management using federal experts in predator control resulted in much greater suppression of predation rates when consistently applied (Engeman et al., 2003, 2005, 2006). The benefits of predator management are most pronounced in years with high nesting, when maximal numbers of hatchlings would result. Here we report the substantial benefits from expert predator management during an exceptional nesting year at the Refuge and place the results in an economic context relative to predator management expenditures.

\section{Study area}

The beach is located on northern Jupiter Island (Fig. 1), a narrow, 27-km-long barrier island along Florida's east coast. Hobe Sound National Wildlife Refuge occupies 298 ha and protects a $5.3-\mathrm{km}$ segment of beach (U.S. Fish \&

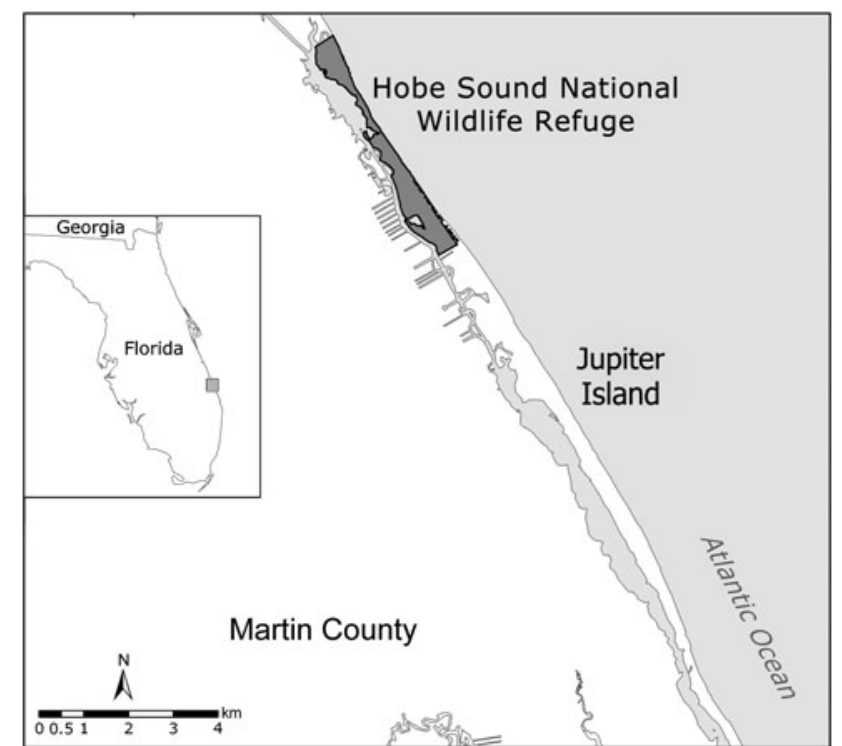

FIG. 1 The location of Jupiter Island in Florida (inset) and the Hobe Sound National Wildlife Refuge beach on Jupiter Island.

Wildlife Service, 1996), which varies in slope and width but has a well-defined dune line. The Refuge beach is open to the public during daylight hours but is accessible only by boat or by foot from its southern boundary.

\section{Methods}

\section{Predator removal methods}

A comprehensive environmental assessment identified lethal predator removal as the only practical and legal approach for reducing nest predation (U.S. Fish \& Wildlife Service, 2000). The predator species are largely nocturnal and removal efforts were conducted 5 nights per week (during property closure), which also minimized the potential for human interference. Raccoons and all armadillos were removed from the beach using a noisesuppressed rifle and night vision equipment to maximize hunting success while minimizing disturbance. Raccoons were also captured in live traps and euthanized but practical and effective techniques were not available for trapping armadillos. Predator control was carried out by U.S. Department of Agriculture/Wildlife Services, the federal agency with responsibility for managing conflicts with wildlife (U.S. Department of Agriculture et al., 1997), using only approved and humane methods to euthanize animals conforming to guidelines in the 2000 Report of the American Veterinary Medical Association Panel on Euthanasia (American Veterinary Medical Association, 2001) and set forth as agency policy in USDA/APHIS/WS Directive 2.505. The applied techniques had been specifically identified as appropriate for Hobe Sound National Wildlife Refuge in the environmental assessment (U.S. Fish \& Wildlife Service, 2000). 
Previous research on monitoring predators at the Refuge beach demonstrated that raccoon activity is minimal until just after loggerhead turtles begin nesting en masse whereas armadillos tend to focus on nest predation after the raccoons (Engeman et al., 2003). Predators were therefore removed during turtle nesting/hatching to maximize practicality and efficacy.

\section{Monitoring turtle nesting and hatching}

Beginning in March 2008, the beach was monitored daily for nest deposition, with all marine turtle nests counted the morning after deposition. All green, leatherback and Kemp's ridley turtle nests were marked for monitoring reproductive success. Approximately $70-90 \%$ of the nests deposited at the Refuge are by loggerhead turtles. Previously established protocol was applied for loggerhead turtle nests: the high number allowed a sample of every eighth nest to be monitored (Engeman et al., 2005, 2006). Beginning with the first day of deposition every eighth loggerhead nest observed sequentially along the beach was marked, with the sequence continuing the following day from where it finished the day before. After locating the nest by careful excavation, a $120-\mathrm{cm}$ stake placed on the north-south axis $60 \mathrm{~cm}$ from the clutch, and two $60-\mathrm{cm}$ stakes placed $60 \mathrm{~cm}$ east and west of the clutch were labelled with observation date, location and turtle species, and joined by surveyor's tape. Redundancy in identifying stakes on precise compass axes at a precise distance from the clutch made nest relocation easy and accurate, even if one or two marking stakes were lost (a rare occurrence). Marked nests were monitored daily for depredation, hatchling emergence, tidal overwash, erosion or other disturbance. Three days after the first observed hatchling emergence marked nests were excavated to determine reproductive success. Nests exhibiting no signs of hatchling emergence were excavated after 70 days for loggerhead and green turtles and 80 days for leatherback turtles. The numbers of hatched and unhatched eggs, live and dead hatchlings, and live and dead embryos in pipped eggs were recorded. All live hatchlings were handled and released in accordance with Florida's Sea Turtle Conservation Guidelines (Florida Fish and Wildlife Conservation Commission, 2007).

\section{Data analyses}

The ultimate measure of annual predation for the Refuge has been the overall percentage of nests lost to predation, which has also been the benchmark criterion for assessing success at protecting nests and monitoring trends (Engeman et al., 2003, 2005, 2006). The numbers of nests deposited were known exactly for all turtle species and fates were known for all nests of green, leatherback and Kemp's ridley turtles because all of their nests were monitored. However, the total number of loggerhead turtle nests predated was estimated by multiplying the total number of loggerhead nests by the proportion predated from the random sample of loggerhead nests that were monitored.

We used data on number of nests, mean clutch size and emergence rate for each species from nests not destroyed by any cause, and predation rates on each species' nests to estimate the number of hatchlings of each species lost to predation in 2008. These established calculations are summarized in the equation (Engeman et al., 2003, 2005, 2010) $L_{i}=N_{i} \times C_{i} \times E_{i} \times P_{i}$, where $L_{i}=$ number of hatchlings of the $i$ th species predicted lost to predation in 2008, $N_{i}=$ number of nests for the $i$ th species in 2008, $C_{i}=$ average clutch size for the $i$ th species in 2008, $E_{i}=$ emergence rate for $i$ th species in 2008 (undamaged nests only), $P_{i}=$ predation rate on the $i$ th species' nests in 2008, and $i=$ loggerhead, green, leatherback or Kemp's ridley turtle. Conversely, if $Q_{i}$ is the proportion of nests for the $i$ th species not destroyed by any cause, then by inserting $Q_{i}$ for $P_{i}$ in this equation we can estimate the number of emerging hatchlings of each species.

We further calculated estimates using established methodology (Engeman et al., 2003, 2005) of how the losses from 2008 would compare to past predator management approaches where experts were not used for predator removal. In particular, we compared the current losses to expected losses estimated if no predator management had been in place and historical high predation of $95 \%$ had occurred. We also estimated losses for the typical level of predation $(50 \%)$ when predator management had been applied by refuge staff not expert in predator removal, in addition to their other duties. These estimates were accomplished by using 0.95 and 0.5 for $P_{i}$ in the above equation, respectively, for the two scenarios.

\section{Results}

The 2008 total of 1,600 marine turtle nests of the four species was the second highest number recorded since sophisticated nest observations were initiated in 1997 (Ecological Associates, 2008). The 1,264 nests by loggerhead turtles exceeded the long-term median of 1,195. Green turtles had a record number of nests (263), over twice the median of 111, leatherback turtles also had a record number of nests (72), twice the median of 36 , and there was a single Kemp's ridley nest, the first observed during the current (1997-2008) period of observation and record keeping.

Turtle nesting parameters, overall and for each species individually, are given in Table 1, along with resulting estimated numbers of hatchlings lost to predation, for each species and overall, and also estimated for the scenarios of no predator control ( $95 \%$ predation) and predator control as an ancillary duty (50\% predation). The $14.7 \%$ overall predation rate is among the lowest predation rates recorded for Hobe Sound National Wildlife Refuge, which, coupled 
TABLE 1 Nesting data and estimated hatchling losses under different nest predation scenarios (95\% loss, the scenario if there is no predator control; $50 \%$ loss, the scenario if predator control is an ancillary duty for Reserve staff) for loggerhead Caretta caretta, green Chelonia mydas, leatherback Dermochelys coriacea and Kemp's ridley Lepidochelys kempii marine turtles in 2008 at Hobe Sound National Wildlife Refuge, Jupiter Island, Florida (Fig. 1).

\begin{tabular}{|c|c|c|c|c|c|}
\hline & Loggerhead & Green & Leatherback & Kemp's ridley & Total \\
\hline No. of nests & 1,264 & 263 & 72 & 1 & 1,600 \\
\hline Mean clutch size & 114.9 & 118.2 & 83.4 & 118.0 & \\
\hline Mean \% emergence & 89.6 & 81.8 & 72.2 & 97.5 & \\
\hline$\%$ nest predation & 12.4 & 28.5 & 5.6 & 0 & 14.7 \\
\hline$\%$ nests not destroyed (any cause) & 59.0 & 61.6 & 88.9 & 100.0 & 60.8 \\
\hline $\begin{array}{l}\text { Estimated no. of hatchlings } \\
\text { emerged }\end{array}$ & 76,648 & 15,669 & 3,851 & 115 & 96,283 \\
\hline $\begin{array}{l}\text { Estimated no. of hatchlings } \\
\text { lost to predation }\end{array}$ & 16,055 & 7,254 & 241 & 0 & 23,550 \\
\hline $\begin{array}{l}\text { Estimated no. of hatchlings } \\
\text { lost if predation }=95 \%\end{array}$ & 123,500 & 24,165 & 4,115 & 109 & 151,889 \\
\hline $\begin{array}{l}\text { Estimated no. of hatchlings } \\
\text { lost if predation }=50 \%\end{array}$ & 65,000 & 12,719 & 2,166 & 58 & 79,943 \\
\hline
\end{tabular}

with the high number of nests, resulted in an exceptional number of hatchlings emerging. Overall, an estimated 128,339 fewer hatchlings were lost to nest predation in 2008 than if no predator management had been applied, and an estimated 56,393 fewer lost than had predator management been carried out as an ancillary Refuge duty.

Of the only four leatherback nests predated, two were by raccoons and two by armadillos. Raccoons played a more minor role in predation on loggerhead and green turtle nests. For loggerhead turtles, armadillos predated $68-71 \%$ of nests and raccoons 6-10\% (one nest had both raccoon and armadillo tracks on the night of depredation, with no indication of the primary excavator). A potential concern is that one loggerhead nest was depredated by a dog species but there was no means to distinguish whether it was a domestic dog Canis familiaris or a coyote, a rapidly expanding invasive species in Florida, including possible sightings on Jupiter Island (the coyote is a highly destructive invasive nest predator elsewhere; RE, BC, AD \& JW, pers. obs.). Armadillos were even more prevalent as nest predators of green turtle nests, with $76-83 \%$ of nest predation, compared to $9-16 \%$ by raccoons (five nests had both raccoon and armadillo tracks in them on the night of depredation, with no indication of the primary excavator).

\section{Discussion}

The 2 years of lowest predation recorded at Hobe Sound National Wildlife Refuge were 2002 and 2007, with overall predation of 9.4 and 9.1\%, respectively (Engeman et al., 2005; Ecological Associates, 2008). However, there were only 1,238 and 1,181 nests respectively in 2002 and 2007 (Engeman et al., 2005, Ecological Associates, 2008), fewer than the 1,600 deposited in 2008. Thus, the number of nests unscathed by predation was far lower in those years than
2008, which had a slightly higher predation rate. In contrast, 1998 had the highest number of nests, with 1,658 recorded nests, but $49.8 \%$ were predated as this was prior to applying expert predator management (Engeman et al., 2003, 2005). Thus, 2008 was an historical year for hatchling production. The 1998 nesting results also demonstrated that extremely high densities of nests do not saturate the predators' abilities to depredate a high proportion of those nests. Conversely, the 2002 and 2007 results demonstrated that the proportion of nests depredated can be held to nominal levels during years with fewer nests, when each nest lost represents a larger proportion of the total (see also Engeman et al., 2005). While Refuge management is unlikely to influence the number of nests deposited, it can influence the success of those nests. The most effective way to increase successful nesting has been to deter nest predation. Thus in 2008 the application of effective predator management in a high nesting year proved an ideal combination for producing large numbers of hatchling turtles.

Loggerhead nesting in Florida, including at Hobe Sound National Wildlife Refuge, had been declining in preceding years (Witherington et al., 2009). The 2008 results were an improvement over 2007 when only about two-thirds as many loggerhead turtles nests (857) were deposited, the lowest recorded annual nesting. Since 1997, and especially after 2006, green and leatherback turtles have substantially increased their nesting at the Refuge. The Kemp's ridley nest is noteworthy as it is the first recorded there. The main nesting site for Kemp's ridley turtles is Rancho Nuevo, Tamaulipas, Mexico, but isolated nesting has been occurring elsewhere, including on both coasts of Florida (Johnson et al., 1999).

The predation rate of green turtle nests at the Refuge was over twice that of loggerhead turtles and over five times that 
for leatherback turtles. Much higher predation on green turtle nests has been previously recorded (Engeman et al., 2005). The low predation rate of leatherback turtle nests is not surprising because, of the three main turtle species, this species initiates nesting first, in deeper nests, in lower numbers, and before predators are conditioned to the presence of turtle nests on the beach. Green turtle nests are less common than those of loggerhead turtles, buried a little deeper on average, and incubated for about the same amount of time. However, green turtles initiate nesting after loggerhead turtles have already begun nesting en masse. Perhaps predators are well-conditioned to seeking turtle nests by the time green turtle eggs have been deposited. Moreover, armadillos tend to initiate predation later in the nesting season than raccoons (Engeman et al., 2003), and armadillos are now responsible for most of the depredated nests at the Refuge. This is mainly because of the much greater efficacy of removing raccoons, with more tools and strategies available to manage their numbers on the beach than for armadillos. Thus, it may be because green turtle nests are deposited and incubating after armadillos have become well conditioned to nest predation that their predation rate was higher.

The success of conservation measures is usually evaluated on the basis of resource improvement but an economic perspective allows managers to assess fiscally the rewards for budgetary expenditures on conservation issues. Neither the lack of predation control nor predation control as ancillary duty required a specific outlay of non-trivial funds, whereas the investment in 2008 for expert predator management was USD 12,000. However, this expenditure equates to only USD 0.09 per additional hatchling compared to no predation control and only USD 0.21 compared to predation control as ancillary duty. Another perspective on the relative economic returns can be derived by applying the methods described by Bodenchuk et al. (2002) and Engeman et al. (2002b, 2004), and specifically applied to hatchling marine turtles by Engeman et al. (2002a). Compared to the scenario of no predator control, the value of additional hatchlings produced was USD 1,069 for every dollar spent on control. Compared to the scenario of control as refuge ancillary duties, the value of additional hatchlings produced was USD 470 for every dollar spent on control. In terms of prioritizing expenditures, maintenance of an active predator control programme could represent one of the most economically and biologically rewarding allocations of management resources.

On beaches where nest predation is inconsequential expenditures on predator management may not be the best allocation of funds. This illustrates the need for a monitoring programme to determine nest fate and predator activity. It is possible to overlook or not recognize predation, miss predator activity if surveys are too infrequent, or incorrectly identify the responsible predator. This information is vital to evaluate the necessity, focus and strategies for predator management, if needed.

On beaches with histories of high losses of turtle nests from predation effort should be made to ensure predators are managed during the entire nesting/hatching season (Engeman et al., 2006). Without predator removal, predation by each of the predator species would probably escalate during a nesting season (Engeman et al., 2006). Not only will predators already conditioned to feeding on turtle nests continue to do so, and probably become more proficient nest predators through the course of the nesting season, but additional individuals and species may also discover the food source and initiate nest predation. This has already been demonstrated at Hobe Sound National Wildlife Refuge as armadillos do not appear to respond to turtle nesting until later in the season than raccoons (Engeman et al., 2003).

Recent research has indicated that reducing predation of marine turtle and shorebird nests can help offset losses as fisheries bycatch (Wilcox \& Donlan, 2007; Donlan \& Wilcox, 2008). The same logic applies to offset other sources of losses at sea, such as from oil spills. Importantly, predator management is a straightforward, relatively inexpensive conservation approach potentially resulting in many tens of thousands of additional marine turtle hatchlings entering the ocean each year, prompting the question, how can we not afford to manage predators effectively at beaches where they pose a significant threat to turtle reproduction?

\section{Acknowledgements}

We thank the Town of Jupiter Island for the funding that permitted the predator management to take place and thereby allow a historic number of hatchling marine turtles to be produced. Justin Fischer kindly created Fig. 1.

\section{References}

American Veterinary Medical Association (2001) 2000 report of the AVMA panel on euthanasia. Journal of the American Veterinary Medical Association, 218, 669-696.

Bain, R.E., Jewell, S.D., Schw a gerl, J. \& Neely, JR, B.S. (1997) Sea Turtle Nesting and Reproductive Success at the Hobe Sound National Wildlife Refuge (Florida), 1972-1995. Report to U.S. Fish \& Wildlife Service, ARM Loxahatchee National Wildlife Refuge, USA.

Bodenchuk, M.J., Mason, J.R. \& PitT, W.C. (2002) Economics of predation management in relation to agriculture, wildlife, and human health and safety. In Proceedings of the ist International Symposium on the Economics of Wildlife Damage Management (ed. L. Clark), pp. 80-90. Colorado State University, Fort Collins, USA.

Dickman, C.R. \& Doncaster, C.P. (1987) The ecology of small mammals in urban habitats. I. Populations in a patchy environment. Journal of Animal Ecology, 56, 629-640. 
Dodd, JR, C.K. (1988) Synopsis of the Biological Data on the Loggerhead Sea Turtle Caretta caretta (Linnaeus 1758). U.S. Fish \& Wildlife Service Biological Report 88, Washington, DC, USA.

Donlan, C.J. \& Wilcox, C. (2008) Integrating invasive mammal eradications and biodiversity offsets for fisheries bycatch: conservation opportunities and challenges for seabirds and sea turtles. Biological Invasions, 10, 1053-1060.

Drennen, D., Cooley, D. \& Devore, J.E. (1989) Armadillo predation on loggerhead turtle eggs at two national wildlife refuges in Florida, USA. Marine Turtle Newsletter, 1989, 7-8.

Ecological Associates (2008) Hobe Sound National Wildlife Refuge, Jupiter Island, Florida: Results of 2007 Sea Turtle Monitoring. Report to U.S. Fish \& Wildlife Service, ARM Loxahatchee National Wildlife Refuge, USA.

Engeman, R.M., Constantin, B., Gruver, K.S. \& Rossi, C. (2009) Managing predators to protect endangered species and promote their successful reproduction. In Endangered Species: New Research (eds A.M. Columbus \& L. Kuznetsov), pp. 171-187. Nova Science Publishers, Hauppauge, USA.

Engeman, R.M., Duffiney, A., Braem, S., Olsen, C., Constantin, B., Small, P. \& Griffin, J.C. (2010) Dramatic and immediate improvements in insular nesting success for threatened sea turtles and shorebirds following predator management. Journal of Experimental Marine Biology and Ecology, 395, 147-152.

Engeman, R.M., Martin, R.E., Constantin, B., Noel, R. \& Woolard, J. (2003) Monitoring predators to optimize their management for marine turtle nest protection. Biological Conservation, 113, 171-178.

Engeman, R.M., Martin, R.E., Smith, H.T., Woolard, J., Constantin, B. \& Stahl, M. (2006) The impact of predation on sea turtle nests when predator control was removed midway through the nesting season. Wildlife Research, 33, 187-192.

Engeman, R.M., Martin, R.E., Smith, H.T., Woolard, J., Crady, C.K., ShwifF, S.A. et al. (2005) Dramatic reduction in predation on sea turtle nests through improved predator monitoring and management. Oryx, 39, 318-326.

Engeman, R.M., Shwiff, S.A., Constantin, B., Stahl, M. \& Smith, H.T. (2002a) An economic analysis of predator removal approaches for protecting marine turtle nests at Hobe Sound National Wildlife Refuge. Ecological Economics, 42, 469-478.

Engeman, R.M., Shwiff, S.A., Smith, H.T. \& Constantin, B.U. (2002b) Monetary valuation methods for economic analysis of benefits-costs of protecting rare wildlife species from predators. Integrated Pest Management Reviews, 7, 139-144.

Engeman, R.M., Shwiff, S.A., Smith, H.T. \& Constantin, B.U. (2004) Monetary valuation of rare species and imperiled habitats as a basis for economically evaluating conservation approaches. Endangered Species Update, 21, 66-73.

Florida Fish and Wildlife Conservation Commission (2007) Sea Turtle Conservation Guidelines. Florida Fish and Wildlife Conservation Commission, Tallahassee, USA.

Garmestani, A.S. \& Percival, H.F. (2005) Raccoon removal reduces sea turtle nest predation in the Ten Thousand Islands of Florida. Southeastern Naturalist, 4, 469-472.

Hecht, A. \& Nickerson, P.R. (1999) The need for predator management in conservation of some vulnerable species. Endangered Species Update, 16, 114-118.

Hop Kins, S.R. \& Richardson, J.I. (1984) Recovery Plan for Marine Turtles. National Marine Fisheries Service, Washington, DC, USA.

IUCN (2010) IUCN Red List of Threatened Species v. 2010.4. Http:// www.iucnredlist.org [accessed 20 April 2011].

Johnson, S.A., Bass, A.L., Libert, B., Marshall, M. \& Fulk, D. (1999) Kemp's ridley (Lepidochelys kempi) nesting in Florida. Florida Scientist, 62, 194-204.
Martin, R.E., Engeman, R.M., Smith, H.T., Stahl, M. \& Constantin, B. (2005) Cheloniidae (marine turtle) bobcat nest predation. SSAR Herpetological Review, 36, 56-57.

Mroziak, M.L., Salmon, M. \& Rusenko, K. (2000) Do wire cages protect sea turtles from foot traffic and nest predators? Chelonian Conservation Biology, 3, 693-698.

National Marine Fisheries Service \& U.S. Fish \& Wildlife Service (2008) Recovery Plan for the Northwest Atlantic Population of the Loggerhead Sea Turtle (Caretta caretta), and Revision. National Marine Fisheries Service, Silver Spring, USA.

NRC (National Research Council) (1990) The Decline of Sea Turtles. National Academy Press, Washington, DC, USA.

Reynolds, J.C. \& TAPPER, S.C. (1996) Control of mammalian predators in game management and conservation. Mammal Review, 26, 127-156.

Riley, S.P.D., Hadidian, J. \& Manski, D.A. (1998) Population density, survival, and rabies in raccoons in an urban national park. Canadian Journal of Zoology, 76, 1153-1164.

Schmitz, D.C. \& Brown, T.C. (1994) An Assessment of Invasive Non-Indigenous Species in Florida's Public Lands. Florida Department of Environmental Protection, Tallahassee, USA.

Smith, H.T. \& EngEMAn, R.M. (2002) An extraordinary raccoon density at an urban park in Florida. Canadian Field Naturalist, 116, 636-639.

$S_{\text {TANCYK }}$, S.E. (1982) Non-human predators of sea turtles and their control. In Biology and Conservation of Sea Turtles (ed. K.A. Bjorndal), pp. 139-152. Smithsonian Institution Press, Washington, DC, USA.

U.S. Congress (1993) Harmful Non-Indigenous Species in the United States. Office of Technology Assessment, OTA-F-565, Government Printing Office, Washington, DC, USA.

U.S. Department of Agriculture/Animal and Plant Health Inspection Service, U.S. Department of Agriculture/Forest Service and Department of Interior/Bureau of Land Management (1997) Animal Damage Control Program Final Environmental Impact Statement (Revised). USDA/Animal and Plant Health Inspection Service, Washington, DC, USA.

U.S. Fish \& WildLIFE SERVICE (1994) Endangered and threatened wildlife and plants. Federal Register, 50, 17.11-17.12.

U.S. Fish \& Wildlife Service (1996) Hobe Sound National Wildlife Refuge. Department of Interior/U.S. Fish \& Wildlife Service publication, RF 41561, Washington, DC, USA.

U.S. Fish \& Wildlife Service (2000) Environmental Assessment for the Management of Predation Losses to Sea Turtle Nests at the Hobe Sound National Wildlife Refuge, Martin County, Florida. U.S. Fish \& Wildlife Service, Hobe Sound, USA.

Wilcox, C. \& Donlan, C.J. (2007) Compensatory mitigation as a solution to fisheries bycatch-biodiversity conflicts. Frontiers in Ecology and the Environment, 5, 325-331.

Williams-Walls, N.J., O’Hara, J., Gallagher, R.M., Worth, D.F., Peery, B.D. \& Wilcox, J.R. (1983) Spatial and temporal trends of sea turtle nesting on Hutchinson Island, Florida, 19711979. Bulletin of Marine Science, 33, 55-66.

Witherington, B., Bressette, M. \& Herron, R. (2006) Chelonia mydas-green turtle. Chelonian Research Monographs, 3, 90-104.

Witherington, B., Kublis, P., Brost, B. \& Meylan, A. (2009) Decreasing nest counts in a globally important loggerhead sea turtle population. Ecological Applications, 19, 30-54.

Woolard, J., Engeman, R.M., Smith, H.T. \& Griner, J. (2004) Cheloniidae (marine turtle) nest predation. SSAR Herpetological Review, 35, 379-380. 


\section{Biographical sketches}

RICHARD ENGEMAN develops methods for practical, quantitatively valid wildlife indexing and ecological sampling and to value rare species and habitats for use in bioeconomic analyses. ERIK MARTIN researches the ecology, conservation and management of marine turtle nesting, with an emphasis on collection and analysis of reproductive parameters. JOHN WOOLARD applies wildlife management methods and collects scientific data. MARGo STAHL manages the Hobe Sound National Wildlife Refuge and focuses on preservation and conservation of habitats and species, with a focus on nesting marine turtles. Charles Pelizza manages the Pelican Island and Archie Carr National Wildlife Refuge, concentrating on conservation of habitats and species, with a focus on nesting marine turtles. ANTHONY DUfFiney focuses on managing humanwildlife conflicts using practical and environmentally sound methods. Bernice Constantin recently retired as Florida State Director for USDA/Wildlife Services where he focused on developing strategies and implementing methodologies for the resolution of human-wildlife conflicts. 